\title{
Simocybe montana (Crepidotaceae, Agaricales), a new species from the alpine belt in the Swiss Alps and the Romanian Carpathians
}

\author{
Egon Horak • Anna Ronikier
}

Received: 24 June 2010 /Revised: 27 September 2010 / Accepted: 28 September 2010 /Published online: 28 October 2010

(C) The Author(s) 2010. This article is published with open access at Springerlink.com

\begin{abstract}
This paper describes the newly discovered species Simocybe montana, which grows in the alpine belt of the European mountains. The species is characterized by a central stipe, large (especially broad), broadly ellipsoid to amygdaliform spores, and occurrence on calcareous soils in the alpine belt. Full description and illustrations of macroand micromorphological features of the new taxon are provided.
\end{abstract}

Keywords Basidiomycota $\cdot$ Alps · Carpathians · Taxonomy

\section{Introduction}

In the pertinent taxonomical literature, the interpretation, circumscription, and typification of the genus Simocybe P. Karst. (1879, Bidrag Kännedom Finlands Natur Folk 32: xxii, 416 nom. cons. - type species $S$. centuncula (Fr.) P. Karst.) were disputed for many years. In the past, selection of various generic type species also caused confusion and controversy concerning the morphotaxonomic range of

Taxonomical novelties: Simocybe montana E. Horak \& A. Ronikier

E. Horak $(\bowtie)$

Schlossfeld 17-C4,

6020 Innsbruck, Austria

e-mail: sporax@gmx.net

\section{A. Ronikier}

Department of Mycology, Institute of Botany,

Polish Academy of Sciences,

Lubicz 46,

PL-31-512 Kraków, Poland

e-mail: a.ronikier@botany.pl characters supposed to be typical for species presently accommodated in Simocybe. Following modern concepts of the genus, relatively few taxa belong to Simocybe (Horak 1968, 2005; Singer 1986; Senn-Irlet 2008). In the course of the taxonomical redefinition of the genus, several species originally described in Naucoria, Ramicola, or Crepidotus were eventually transferred to Simocybe (Romagnesi 1943; Singer 1950; Bon 1991; Ludwig 2001; Moreau et al. 2007; Courtecuisse 2008). As a consequence, about ten species from the genus are currently recognized in Europe.

The genus Simocybe belongs to the Crepidotaceae and, based on phylogenetic analyses, appears to be monophyletic and most closely related to Crepidotus (Moncalvo et al. 2002; Aime et al. 2005; Petersen et al. 2010). Its close relationship to Crepidotus is manifested by morphological resemblance of some species, and thus difficulties in delimitation of the genus Simocybe still exist (e.g. Bandala et al. 2008a, b; Courtecuisse 2008).

According to the generic diagnosis, the most distinctive macroscopical characters for species referred to Simocybe are small, brown basidiomes (often with olive tinge) with micaceous or minutely pruinose pileus, emarginate or subdecurrent brown lamellae, central or eccentric pruinose stipe, and absence of veil remnants on both pileus and stipe. Microscopically, species of Simocybe are recognized by the cellular pileipellis structure composed by a continuous turf of polymorphic cells (often intermixed with distinctive pileocystidia), presence of conspicuous cheilocystidia and caulocystidia and smooth, brown, ovoid, amygdaliform or phaseoliform spores usually without a germ pore (but occasionally with callus). All described species are saprobic and are reported to grow on rotting plant debris (wood, bark, leaves, stems) or on decaying moss. 
Confirmed records of Simocybe are relatively scarce. The most comprehensive contributions were published for the following geographical regions: North America (Murrill 1912; Redhead and Cauchon 1989; Horak and Miller 1997), neotropical South America (Singer 1973), Southeast Asia (Horak 1980c, Borneo; Horak 1980b, Papua New Guinea), and Australasia (Horak 1980a, New Zealand; Horak 1980c, Australia).

The ecological-geographical range of localities for Simocybe records spans tropical-subtropical regions to arctic-alpine habitats and rarely also to localities at high latitudes in the Arctic and Antarctic.

The European species of Simocybe are keyed out and/or monographed by Reid (1984), Watling and Gregory (1989), Bon (1992), Senn-Irlet (1995, 2008), Ludwig (2001) and Horak (2005). Because these works do not include the revision of the recently described species, a detailed and updated European monograph of the genus is greatly needed.

The aim of the present paper is to describe a newly discovered species of Simocybe growing in the alpine belt of the European mountains.

\section{Material and methods}

Specimens were collected in the alpine zone of the Swiss Alps and the Romanian Carpathians. Macromorphological characters were described from specimens in fresh condition. The colour picture was taken in the field. The description provided below is based on specimens collected in the Alps and in the Romanian Carpathians. Colour codes in macroscopical description refer to Kornerup and Wanscher (1965). For the analysis of microscopical characters (pileipellis, stipitipellis and lamellar edges), fragments taken from exsiccata were rehydrated in destilled water and subsequently mounted in $4 \% \mathrm{KOH}$ and Congo Red. Voucher material is kept in Herbarium ZT (Zurich, Switzerland) and Herbarium KRAM (Cracow, Poland).

\section{Taxonomy}

Simocybe montana E. Horak \& A. Ronikier, spec. nov. MycoBank no.: MB 518917

Figures $1-8$.

Etymology - montanus (Lat.), belonging to the mountains. Pileus (8)10-12 mm, primo convexus (vel subumbonatus) dein applanato-depressus, ochraceoargillaceus vel aureobrunneus, pallide olivaceo tinctu, opacus, hygrophanicus, siccus, minute micaceus vel innate fibrillosus, marginem versus substriatus. Lamellae 16-24, 3(7) lamellulae, adnatae, emarginatae vel subdecurrentes, pallide argillaceobrunneae, albofimbriatae. Stipes $8-18 \times 1$ $1.5 \mathrm{~mm}$, centralis, cylindricus, pileo concolor vel pallidior, ad apicem minute pruinosus, basim versus fibrillis concoloribus obtectus, siccus. Velum nullum. Caro concolor, immutabilis. Odor saporque aciduli vel nulli. Sporae in cumulo fuscobrunneae. Sporae (8.5)9-11×(5.5)6-7(7.5) $\mu \mathrm{m}$, late ellipsoideae, vel amygdaliformes, brunneae, leves. Basidia 26-32 $\times 7-8 \mu \mathrm{m}$, 4-sporigera, fibulata. Cheilocystidia (30)40-55(60) $\times 4-7 \mu \mathrm{m}$, polymorphica, ex clavato fusoidea, rare bifurcata, hyalinia. Pleurocystidia nulla. Caulocystidia 25-55 $\times 5-8 \mu \mathrm{m}$, cheilocystidiis similia. Pileipellis ex cellulis clavatis vel fusoideis hymenidermium formantibus, rare bifurcatis, pigmento brunneo incrustatis. Fibulae praesentes. Holotypus E. Horak 1334 (ZT).

Pileus (8)10-12 mm, at first convex (occasionally with inconspicuous, blunt umbo) soon becoming expanded with weakly depressed centre, beige-ochre-brown, golden yellow-brown or orange-brown with pale olive tint (5EF7) when moist, opaque, hygrophanous, changing to pale ochre-fawn on drying, weakly striate towards margin, dry, minutely micaceous or innately fibrillose, veil remnants absent (Figs. 1, 7, 8). Lamellae 16-24 reaching stipe, 3(7) lamellulae, rather distant, adnate, emarginate or subdecurrent, ventricose in aged specimens, pale beige-brown (occasionally with faint olive tinge), whitish or darker edges fimbriate or crenate. Stipe $8-18 \times 1-1.5 \mathrm{~mm}$, central, cylindrical, terete, concolorous or paler as pileus, upper half minutely pruinose, smooth or appressed fibrillose towards base, dry, solitary, solid becoming fistulose in age, veil remnants absent. Context concolorous or paler as pileus, unchanging on exposure. Odor not distinctive or acidulous. Taste like odor. Chemical reaction on pileus: $\mathrm{KOH}$ negative.

Spore print (dark) brown. Spores (8.5)9-11 $\times(5.5) 6-7$ (7.5) $\mu \mathrm{m}, \mathrm{Q}=1.3-1.6$, broadly ellipsoid or amygdaliform, brown, smooth, wall often thickened (up to $1 \mu$ ), occasionally with callus (obscure germ pore) at apex (Fig. 2). Basidia 26-32×7-8 $\mu \mathrm{m}$ (4-spored), clamped; 30-36 ×7-8 (2-spored) (Fig. 3). Cheilocystidia (30)40-55(60) $\times 4-7 \mu \mathrm{m}$, polymorphic, shape ranging from slender clavate to slender fusoid, occasionally forked, thin-walled, hyaline (Fig. 4). Pleurocystidia absent. Caulocystidia $25-55 \times 5-8 \mu \mathrm{m}$, polymorphic, shape like cheilocystidia but apex often capitate (up to $13 \mu \mathrm{m}$ diam. at capitate apex), thin-walled, hyaline (Fig. 5). Pileipellis a hymeniderm composed of a layer of clavate or vesiculose cells, occasionally forked or constricted, walls thin, strongly incrusted with brown pigment (Fig. 6). Oleiferous hyphae absent. Clamp connections present.

Habitat/Substrate Saprobic. On bare soil (in snow bed) among Salix herbacea (E. Horak 1334, ZT, holotype), on bare soil among Salix herbacea, Dryas octopetala, and Carex firma (E. Horak 2280, ZT), or on sandy soil among 
Figs. 1-7 Simocybe montana, sp. nov. 1-7 (holotype, E. Horak 1334, ZT): 1 Basidiomes (nat. size, bar $=20 \mathrm{~mm}$ ). 2 Basidiospores $(\times 2000$, bar $=10 \mu \mathrm{m})$. 3 Basidia (4-spored and 2-spored, $\times 1000$, bar $=20 \mu \mathrm{m})$. 4 Cheilocystidia $(\times 1000$, bar $=20 \mu \mathrm{m}) .5$ Caulocystidia $(\times 500$, bar $=40 \mu \mathrm{m}) .6$ Pileipellis $(\times 500$, bar $=40 \mu \mathrm{m}) .7$ Basidiomes (E. Horak 2280, ZT, nat. size, $b a r=20 \mathrm{~mm}$ )

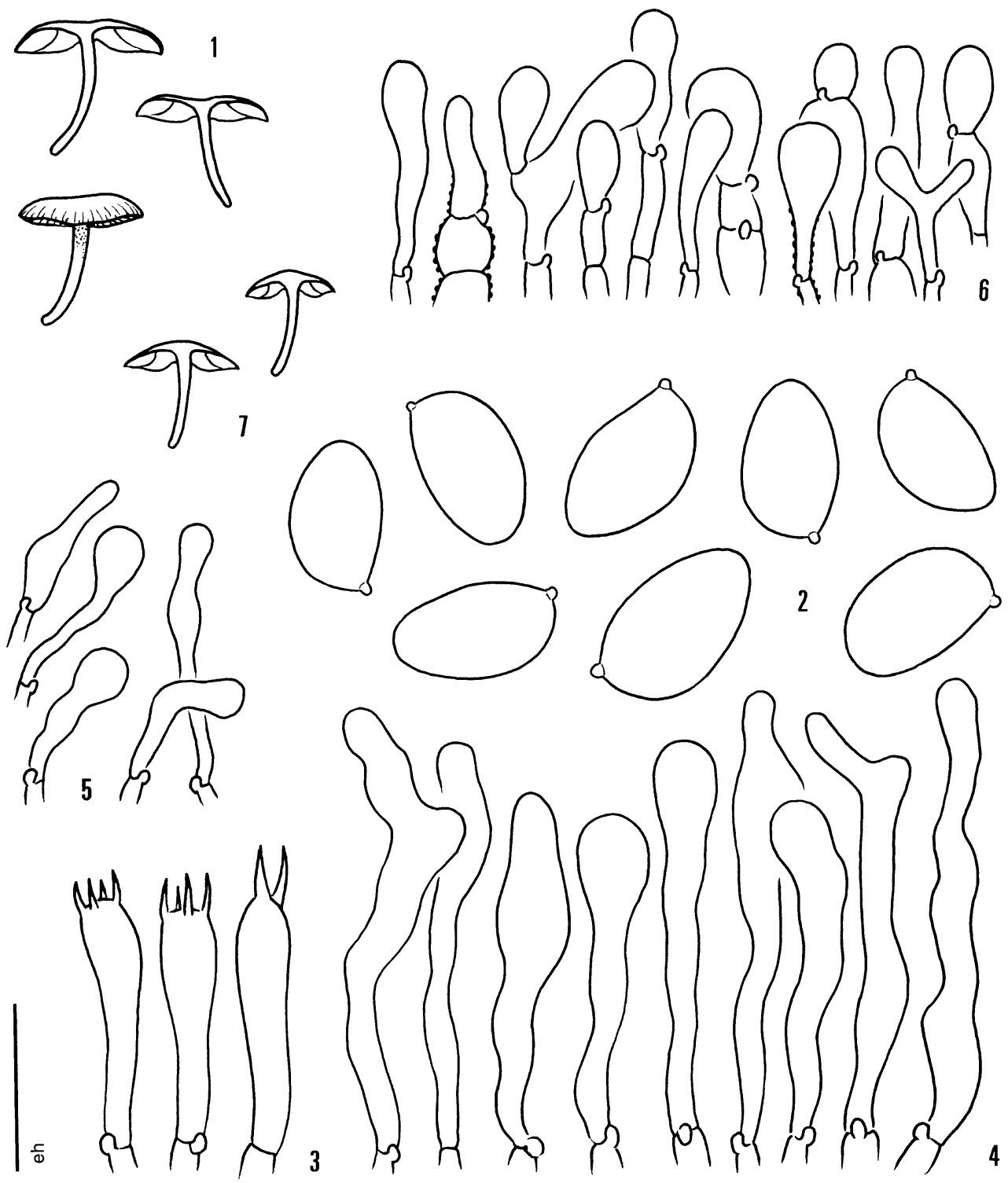

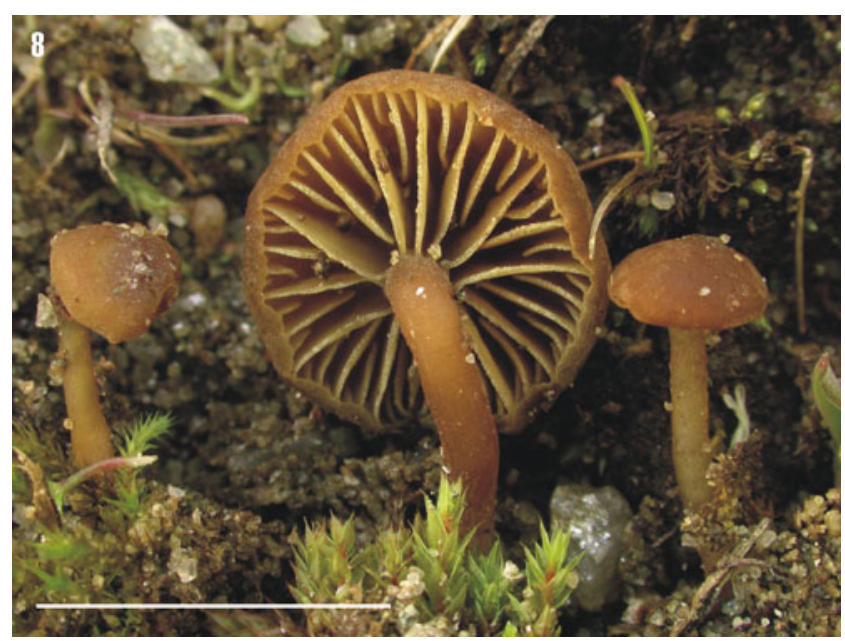

Fig. 8 Simocybe montana, sp. nov. (KRAM F-46739, bar=10 mm) moss and Polygonum viviparum (KRAM F-46739). All three records were gathered on dolomite, limestone, or limestone conglomerates.

Phenology September (Swiss Alps), end of July (Romanian Carpathians).

Specimens examined Romania, Județul Dâmbovița, Southern Carpathians, Munții Bucegi, near the refuge hut Cabana Babele, N 45²4'22”, E 25²8'21', $2200 \mathrm{~m}$ alt., on sandy soil in alpine meadow among moss and Polygonum viviparum, on limestone conglomerate, 31 Jul. 2006, leg. A. Ronikier, M. Ronikier and H. Knudsen (KRAM F-46739, E. Horak 13199, ZT). Switzerland, GR, Val S-charl, Costainas, $2480 \mathrm{~m}$ alt., in swampy soil under Salix herbacea, snow bed, on dolomite (limestone), 8 Sep. 1981, leg. E. Horak 1334 (ZT, holotype); GR, Ofen Pass, NW of Munt de la Bescha, Chaslot, $2400 \mathrm{~m}$ alt., in bare 
soil under Salix herbacea, Dryas octopetala and Carex firma, on dolomite (limestone), 7 Sep. 1983, leg. E. Horak 2280 (ZT).

Distribution Switzerland (type), Romania.

\section{Discussion}

In the field, the basidiomes of Simocybe montana can be mistaken for species from several other genera with brown spore print. The most comprehensive publications on the European arctic-alpine species of Agrocybe, Alnicola, Inocybe, or Tubaria (Favre 1955; Senn-Irlet 1987; Contú 1993; Bon 1997; Ferrari 2006; Jamoni 2008) were examined for any indication of Simocybe montana, but none was found. Other relevant literature on arctic-alpine agarics was consulted in order to find references of (possibly misidentified) taxa that could be contaxic with Simocybe montana. This careful search of descriptive data demonstrated that none of the suspected records could represent a "cryptic" collection of $S$. montana, including e.g. Agaricus lapponicus Fr. (Rostrup 1894; Ferdinandsen 1910, both from NE- and E-Greenland), Naucoria macrospora J.E. Lange (Møller 1945, from the Faeroes; Kobayasi et al. 1971, from W-Greenland), Naucoria arctica Lebedeva (Lebedeva 1927, from northern Siberia), or Naucoria bellotiana Berk. (Berkeley 1878, from Bellot Island, NE-Canada).

The following combination of characters distinguish Simocybe montana from all other species in the genus: central stipe, relatively large and broad, (8.5)9-11 $\times(5.5) 6-7$ (7.5) $\mu \mathrm{m},(\mathrm{Q}=1.3-1.6)$, broadly ellipsoid to amygdaloid spores that are never phaseoliform, and occurrence on bare (calcareous) soil above timberline in alpine habitat.

Representatives of the genus Simocybe were also reported in several localities in western Antarctica. One species, $S$. antarctica Pegler, was found growing on decaying moss. Macroscopically, the small, Crepidotus-like basidiomes of $S$. antarctica (Pegler et al. 1980; Horak, unpubl.) are remarkable due to the cyphelloid habitat with the absent or reduced lateral stipe. This is another species in the genus exclusively recorded from habitats with cold climate.

Among the European representatives of Simocybe, two ecologically differentiated groups of species can be recognized. One group consists of fungi associated with wood of mostly deciduous trees and includes the following species: S. centunculus (Fr.: Fr.) Singer (incl. var. obscura (Romagn.) Singer), S. coniophora (Romagn.) Watling, $S$. geraniolens (Clowez \& G. Díaz) E. Ludwig, S. haustellaris (Fr.: Fr.) Watling $[=S$. rubi (Berk.) Singer] and $S$. sumptuosa (P.D. Orton) Singer.

The second group includes species associated with nonwoody plant remnants or occurring on soil, e.g. S. laevigata
(J. Favre) P.D. Orton (incl. var. maritima Bon) associated with decaying sedges, S. arciensis (Contú) P.-A. Moreau \& C. Lavoise, a species growing on Juncus and possessing spores with a small germ pore (Moreau et al. 2007) and $S$. reducta (Fr.: Fr.) P. Karst., a very rare species that can be found among grasses, on soil or rarely also on wood. The newly described $S$. montana belongs to the second group, but it appears to occur on bare soil and is probably not associated with plant remnants.

So far, only three species of Simocybe have been recorded in arctic-alpine sites in the northern hemisphere: Simocybe haustellaris (Fr.: Fr.) Watling from southern Greenland (Elborne and Knudsen 1990; Senn-Irlet 1991), S. laevigata (J. Favre) P.D. Orton $(=S$. centunculus var, laevigata (J. Favre) Senn-Irlet) from the French Alps (Kühner and Lamoure 1986) and S. montana from the Swiss Alps and the Carpathian Mountains in Romania. The first two species are widespread in Europe and are not restricted to arctic-alpine regions. $S$. haustellaris is associated with wood of deciduous trees (e.g. Horak 2005; SennIrlet 2008) and its presence in Greenland is limited to the southernmost subarctic region, the area where trees (Betula pubescens) have their northernmost localities. S. laevigata occurs at the base of sedges and has been found in moist localities (Trichophoretum caespitosum, Kühner and Lamoure 1986). To date, Simocybe montana is exclusively known from the alpine belt and it may represent a typical arctic-alpine species. The three aforementioned collections were found on calcareous bedrock, and accordingly the species may be considered to be calciphilous. More records are needed, however, to characterize the specific ecological and biogeographical properties of S. montana.

Acknowledgments The research was partly supported by the Polish Ministry of Science and Higher Education (grants no. 2P04C 08630 and N N303 308237).

Open Access This article is distributed under the terms of the Creative Commons Attribution Noncommercial License which permits any noncommercial use, distribution, and reproduction in any medium, provided the original author(s) and source are credited.

\section{References}

Aime MC, Vilgalys R, Miller OK Jr (2005) The Crepidotaceae (Basidiomycota, Agaricales): phylogeny and taxonomy of the genera and revision of the family based on molecular evidence. Amer J Bot 92(1):74-82

Bandala VM, Montoya L, Esteve-Raventós F (2008a) Crepidotus eucalyptinus and Simocybe haustellaris: two uncommon species found in Central Spain. Mycotaxon 104:369-384

Bandala VM, Esteve-Raventós F, Montoya L (2008b) Two remarkable brown-spored agarics from Spain: Simocybe parvispora sp. nov. and Crepidotus ibericus comb. nov. Sydowia 60(2):181-196 
Berkeley MJ (1878) Enumeration of the fungi collected during the Arctic Expedition, 1875-76. J Linn Soc Bot 17:13-17

Bon M (1991) Espèces galéro-naucorioides: stat. et comb. nov. Doc Mycol 21(83):37-39

Bon M (1992) Clé monographique des espèces galero-naucorioides. Doc Mycol 21(84):1-89

Bon M (1997) Clé monographique des Inocybes alpins. Bull Féd Mycol Dauphiné-Savoie 144:71-109

Contú M (1993) Contributo ad una check list dei funghi della Sardegna. 1. Tre nuove specie de Ramicola (Crepidotaceae). Micol Ital 3:64-67

Courtecuisse R (2008) Novitates. 5. Nouvelles combinaisons et nouveaux noms nécessaires suite à la mise au point du référentiel des noms de champignons présents sur le territoire national métropolitain (1 Basidiomycètes). Doc Mycol 34(135-136):48-52

Elborne SA, Knudsen H (1990) Larger fungi associated with Betula pubescens in Greenland. Meddel Grønland Biosci 33:77-80

Favre J (1955) Les champignons supérieurs de la zone alpine du parc national suisse. Ergebn wiss Untersuch Schweiz Nationalparkes 5:1-212

Ferdinandsen C (1910) Fungi terrestres from NE-Greenland ( $\mathrm{N}$ of $76^{\circ} \mathrm{N}$ Lat.) collected by the "Danmark Expedition". Meddel Grønland 43:137-145

Ferrari E (2006) Inocybe alpine e subalpine. Fungi Non Delineati 34$36: 1-457$

Horak E (1968) Synopsis generum Agaricalium (Die Gattungstypen der Agaricales). Beitr Krypt Flora Schweiz 13:1-741

Horak E (1980a) Fungi Agaricini Novazelandiae. 10. Simocybe Karsten. New Zealand J Bot 18:189-196

Horak E (1980b) New species of Simocybe (Karst. (Agaicales) from Papua New Guinea. Sydowia 32:123-130

Horak E (1980c) Additional species of Simocybe (Agaricales) from Sabah and Australia. Sydowia 32:181-184

Horak E (2005) Röhrlinge und Blätterpilze in Europa. Spektrum Verlag, Elsevier, Heidelberg

Horak E, Miller OK (1997) A new species of Simocybe from North America. Mycotaxon 62:225-229

Jamoni PG (2008) Funghi alpini delle zone alpine superiori e inferiori. A.M.B. Fondazione, Centro Studi Micologici, Trento

Kobayasi Y, Hiratsuka N, Otani Y, Tubaki K, Udagawa S-I, Sugiyama J, Konno K (1971) Mycological studies of the Angmagssalik region of Greenland. Bull Nat Sci Mus Tokyo 14:1-96

Kornerup A, Wanscher JH (1965) Farver i Farver. Methuen handbook of colour. Politikens Forlag, København

Kühner R, Lamoure D (1986) Catalogue des Agaricales (Basidiomycètes) de la zone alpine du Parc National de la Vanoise et des régions limitrophes. Travaux scientifiques du Parc National de la Vanoise 15:103-187

Lebedeva L (1927) Champignons de la côte arctique de la Sibérie. Trav Comm Etude Rep Aut Sov Soc Iakoute 12:1-23
Ludwig E (2001) Pilzkompendium Band 1 Beschreibungen. Die kleineren Gattungen der Makromyzeten mit lamelligem Hymenophor aus den Ordnungen Agaricales, Boletales und Polyporales. IHW-Verlag, Eching

Moncalvo JM, Vilgalys R, Redhead SA, Johnson JE, James TY, Aime MC, Hofstetter V, Verduin SJW, Larsson E, Baroni TJ, Thorn RG, Jacobsson S, Clémençon H, Miller OK Jr (2002) One hundred and seventeen clades of euagarics. Molec Phylogenet Evol 23:357-400

Møller FH (1945) Fungi of the Faeröes. 1. Basidiomycetes. Copenhagen

Moreau P-A, Corriol G, Borgarino D, Lavoise C (2007) Contribution à la connaissance des champignons de l'étage thermoméditerranéen Corse III. Bull Sem Féd Assoc Mycol Méditerranéennes 31:33-84

Murrill WA (1912) The Agaricaceae of tropical North America. 5. Mycologia 4:72-83

Pegler DN, Spooner BM, Smith RIL (1980) Higher fungi of Antarctica, Subantarctic zone and Falkland Islands. Kew Bull 35:499-562

Petersen G, Knudsen H, Seberg O (2010) Alignment, clade robustness and fungal phylogenetics - Crepidotaceae and sister families revisited. Cladistics 26:62-71

Redhead SA, Cauchon R (1989) A new Simocybe from Canada. Sydowia 41:292-295

Reid DA (1984) A revision of the British species of Naucoria sensu lato. Trans Brit Mycol Soc 82:191-237

Romagnesi H (1943) Etudes complémentaires sur le genre Tubaria et sur deux Naucoria tubarioides. Rev Mycol (Paris) $8: 26-35$

Rostrup E (1894) Øst-Grønlands svampe. Medd Grønland 18:4581

Senn-Irlet B (1987) Ökologie, Soziologie und Taxonomie alpiner Makromyzeten. Agaricales, Basidiomycetes der Schweizer Zentralalpen. Ph.D. Dissertation, Univ. Bern, Bern, 1-252

Senn-Irlet B (1991) Crepidotus, Pellidiscus and Ramicola in Greenland (Agaricales, Crepidotaceae). Nord J Bot 11:587-597

Senn-Irlet B (1995) Die Gattung Simocybe Karsten in Europa. Mycol Helv 7:27-61

Senn-Irlet B (2008) Simocybe P. Karst. In: Knudsen H, Vesterholt J (eds) Funga Nordica. Agaricoid, boletoid and cyphelloid genera. Nordsvamp, Copenhagen, pp 908-910

Singer R (1950) Naucoria Fries in the USSR. Trud Bot Inst Komarov Akad Nauk, ser. 2, 6:402-498

Singer R (1973) The genera Marasmiellus, Crepidotus and Simocybe in the Neotropics. Beih Nova Hedwigia 44:1-517

Singer R (1986) The agaricales in modern taxonomy. Koeltz Scientific Books, Koenigstein

Watling R, Gregory NM (1989) Crepidotaceae, Pleurotaceae and other pleurotoid agarics. Brit Fung Fl 6:1-157 